\title{
Thermoacoustic Computed Tomography
}

National Cancer Institute

\section{Source}

National Cancer Institute. Thermoacoustic Computed Tomography. NCI Thesaurus. Code C116443.

A type of computer tomography that uses radiation to create thermoacustic waves, which are then recorded and translated into a three dimensional image of the tissue. 